\title{
Microsatellite markers for Eucalyptus pilularis (Subgenus Eucalyptus); sourcing genetic markers outside the subgenus
}

\author{
By M. SHEPHERD ${ }^{1), 4), *)}$, C. BihUA ${ }^{2), 4)}$ and R. HenRY ${ }^{3), 4)}$
}

(Received $5^{\text {th }}$ March 2013)

\begin{abstract}
Microsatellite markers remain the most broadly used molecular marker in eucalypt genetics. A major advantage of microsatellite markers is that they often transfer readily between related taxa circumventing the need to develop new markers de novo in each species. Markers have been developed for a number of species of major economic importance, mainly from the Subgenus Symphyomyrtus, but these may also be available for use in species of lesser economic importance from other subgenera. Here we report on the sourcing of microsatellite markers for E. pilularis (Subgenus Eucalyptus (Formerly Monocalyptus)) from species outside the subgenus. Ninety-seven precent ( 60 out of 62 ) of loci that amplified in the source taxon ( $E$. grandis) also amplified in the target taxon $E$. pilularis. By characterising them on a diversity panel $(n=24)$ and a pedigree, a subset of 41 loci were distilled out that could be scored reliably and were polymorphic (Mean unbiased heterozygosity $=0.81$ ). Predictions of efficient microsatellite marker transfer among eucalypts based on low evolutionary divergence have largely been borne out and are congruent with accumulating evidence of low sequence divergence within Eucalyptus. Upon this favourable background for microsatellite marker transfer, this study indicates highly efficient transfer is possible by identifying loci with broad PCR optima and adoption of approaches that favour cross-species transfer.
\end{abstract}

Key words: Monocalyptus, Eucalyptus, Symphyomyrtus, genetic diversity, microsatellite marker, internal transcribed spacer, ITS CCR,

\section{Introduction}

Microsatellite markers remain the most broadly used molecular markers in eucalypt genetics (GRATTAPAGLIA et $a l ., 2012$ ). Their adoption as the preferred marker type for linkage mapping, studies of population diversity and structuring, and relationships amongst individuals and populations of eucalypts, paralleled the uptake in many other species of plants, animals and fungi (BARBARA et al., 2007; GrattaPAGLIA and KIRST, 2008; SchlotTERER, 2001). A major advantage of microsatellite markers is that they often transfer readily between related taxa cir-

1) Southern Cross Plant Science, Southern Cross University, PO Box 157 Lismore, NSW 2480, Australia.

2) Fujian Academy of Forestry Sciences, Fuzhou, Fujian 350012, China.

3) Queensland Alliance for Agriculture and Food Innovation, The University of Queensland, St Lucia 4072 Australia.

$\left.{ }^{4}\right)$ Former address: Centre for Plant Conservation Genetics, Southern Cross University, PO Box 157 Lismore, NSW 2480, Australia.

*) Corresponding Author: Dr. Mervyn ShePherd. E-Mail: Mervyn.Shepherd@scu.edu.au. cumventing the need to develop new markers de novo in each species, hence they may be available for use in studies of species of less economic importance (PEAKALL et al., 1998). Forest tree geneticists have benefited particularly from this feature as it has been widely observed that transfer is most successful for species with long generation times, with mixed, or outcrossing breeding systems (BARBARA et al., 2007), and early predictions of high transfer rates among eucalypts has largely been borne out, and no doubt promoted their widespread application across the group (BYRNE et al., 1996; JoNES et al., 2001; KIRST et al., 1997).

Eucalyptus pilularis Smith (Blackbutt) is a common, tall forest tree found in a wide latitudinal band $\left(25-37^{\circ} \mathrm{S}\right)$ on the east coast of Australia. It is the principal hardwood species for sawn timber in northern NSW (HENSON et al., 2007) and along with E. pyrocarpa, it constitutes the Section Pseudophloius, Subgenus Eucalyptus, in the most recent classification of eucalypts by BROOKER (2000). We have recently investigated the geographical and historical determinants of genetic structure in E. pilularis (SHEPHERD et al., 2010), and the degree of its relationship with $E$. pyrocarpa (SHEPHERD and RAYMOND, 2010) based on genetic variation at microsatellite loci.

Here we report on the sourcing of microsatellite markers for E. pilularis from outside the Eucalyptus subgenus (Formerly Monocalyptus). The eucalypts, in the broad sense, are a group of some 900 species classified into three genera, Eucalyptus, Corymbia and Angophora (HILL and JoHNSON, 1995), with most species of economic importance belonging to either the subgenus Eucalyptus or Symphyomyrtus (ELDRIDGE et al., 1994). The few members of the Eucalyptus subgenus of economic importance, however, means that most genomic resources have been developed in species from subgenus Symphyomyrtus (e.g. E. grandis and E. globulus) (PoKE et al., 2005). For example, a recent review of available genomic resources for the Myrtaceae showed that large numbers (i.e. > 50) of microsatellite markers have been developed in Symphyomyrtus species only (GRATTAPAGLIA et al., 2012).

In one of the largest studies of trans-subgeneric transfer in eucalypts, we test the transfer of 71 loci sourced from $E$. grandis or E. urophylla (BRONDANI et al., 2002; BRONDANI et al., 1998; BRONDANI et al., 2006) to E. pilularis and report genetic diversity parameters for one SSR marker developed de novo. We found comparatively high rates of inter-subgeneric transfer $(97 \%)$ compared to most previous studies in eucalypts (BYRNE et al., 1996; Glaubitz et al., 2001; JoNES et al., 2001; KIRST et al., 1997; SHEPHERD et al., 2006; STEANE et al., 2001). 
This we attributed to a filtering of the tested loci for a subpopulation of PCR robust loci and adoption of reaction conditions favouring transfer in our study.

\section{Methods}

\section{Study design and Materials}

A two stage assessment was used to test for microsatellite marker transfer to $E$. pilularis. In Stage 1 , a set of 71 markers identified in $E$. grandis or $E$. urophylla (Table 1) and a single $E$. pilularis marker were screened on a set of six diverse $E$. pilularis individuals along with two $E$. grandis individuals to test compatibility of the loci with standardised PCR conditions (confirmed by amplification of the positive control $E$. grandis) and conservation of priming sites (confirmed by amplification of $E$. pilularis).

In Stage 2, a more rigorous assessment of the 24 most promising loci was conducted by screening an expanded set of 16 diverse $E$. pilularis individuals plus the two parents and six F1 individuals from a controlled pollinated cross (samples provided by Forests NSW) (total of 24 individuals; Table 2). The E. pilularis selected for this study were chosen to represent a diverse set of loca-

Table 1. - List of the 72 microsatellite markers used in the study. The flurophore and PCR program is listed with each marker as well as the amplification success of the marker (rating), degree of polymorphism and allele size range based on amplification in six E. pilularis individuals.

\begin{tabular}{|c|c|c|c|c|c|c|c|}
\hline Index & Marker & Fluonophore & $\begin{array}{l}P C R \\
\text { prog }\end{array}$ & $\begin{array}{l}\text { Marker } \\
\text { rating }\end{array}$ & $\begin{array}{l}\text { Marker } \\
\text { poly: }\end{array}$ & $U H_{a^{\prime}}^{+}$ & $\begin{array}{l}\text { Allele Range } \\
\text { (bp) }\end{array}$ \\
\hline 1 & I:MI3RA 075 & Pl: & Pt $1 \times 58$ & 0 & - & - & \\
\hline 2 & EMBRA 107 & PET & $\mathrm{l}^{\mathrm{t} T X 54}$ & 0 & - & - & \\
\hline 3 & IMBRA 069 & V]C & ]t $[\times 60$ & 0 & - & - & \\
\hline 4 & FMBR $\triangle 080$ & VIC & PtTX58 & 0 & - & - & \\
\hline 5 & ГMBRA 082 & VIC & PtTX56 & 0 & - & - & \\
\hline 6 & FMBR $A 085$ & $V] C$ & PtTX60 & 0 & - & - & \\
\hline 7 & ГMBRA 089 & VIC & $\operatorname{PtTX56}$ & 0 & - & - & \\
\hline 8 & ENBR 230 & Ved & $\operatorname{PtTX50}$ & 0 & - & - & \\
\hline 9 & ГMßRА 055 & PГ: & PtTX54 & 0 & - & - & \\
\hline 10 & FMBRA 002 & Ved & ]'t $\times 58$ & 1 & - & - & \\
\hline 11 & ГМГЗRА 120 & PГ:T & PtTX56 & 1 & - & - & \\
\hline 12 & EMBRA 020 & $\mathrm{Ved}$ & $\mathrm{P}^{3} \mathrm{tT} \times 56$ & 2 & $\mathrm{M}$ & - & 147 \\
\hline 13 & ЕMBRA 058 & 6ram & ] & 2 & $\mathrm{M}$ & - & 136 \\
\hline 14 & EMBRА 068 & 6ram & $\mathrm{l}^{2} \mathrm{tT} \times 54$ & 2 & $\mathrm{M}$ & - & 106 \\
\hline 15 & EMBRA 092 & $6 \mathrm{Fam}$ & PtTX56 & 3 & $\mathrm{P}$ & - & \\
\hline 16 & FMBRA 113 & Ved & ] $\mathrm{t} T \times 56$ & 3 & $P$ & - & \\
\hline 17 & ГМГЗRА 057 & VIC & PtTX50 & 3 & $\mathrm{P}$ & - & \\
\hline 18 & FMBR 095 & $6 F a m$ & ] $\mathrm{t} T \times 56$ & 3 & $\mathrm{P}$ & - & \\
\hline 19 & FMBRA 224 & $\mathrm{Ved}$ & PtTX60 & 3 & $\mathrm{P}$ & - & \\
\hline 20 & EMBRA 054 & VIC & PtTX54 & 3 & $\mathrm{P}$ & - & \\
\hline 21 & EMBRA 172 & PET & PtTX60 & 3 & $\mathrm{P}$ & - & \\
\hline 22 & l:MI3RA 207 & Pl:T & ]$^{3} \mathrm{tTX} 60$ & 3 & $\mathrm{P}^{\mathrm{P}}$ & - & \\
\hline 23 & EMLRA 061 & VIC & $\mathrm{I}^{\mathrm{T} T} \mathrm{~T} 50$ & 3 & $\mathrm{I}$ & - & \\
\hline 24 & FMBRA 183 & 6Fam & ]$^{3} \mathrm{t} \times 54$ & 3 & $\mathrm{P}$ & - & \\
\hline 25 & ГМГЗRА 003 & $\mathrm{Ved}$ & PtTX58 & 3 & $\mathrm{P}$ & - & \\
\hline 26 & FMBRA 150 & Ved & ] $\mathrm{t}^{\mathrm{T}} \times 50$ & 3 & $\mathrm{P}$ & - & \\
\hline 27 & EMBRA 167 & PET & PtTX50 & 3 & $\mathrm{P}$ & - & \\
\hline 28 & EMBR $\triangle 014$ & VIC & PtTX58 & 3 & $P^{P}$ & - & \\
\hline 29 & EMBRA 034 & VIC & $\operatorname{PtTX54}$ & 3 & $\mathrm{P}$ & - & \\
\hline 30 & $1:$ MI3RA 062 & Gtian & 3tTX50 & 3 & $\mathrm{P}^{\mathrm{P}}$ & - & \\
\hline 31 & EMBRA 166 & Ved & $\mathrm{P}^{\mathrm{t}} \mathrm{tT} \times 50$ & 4 & $\mathrm{P}^{\mathrm{P}}$ & 0.91 & $83-108$ \\
\hline 32 & FMBR 0081 & $P F[$ & ]$^{3} \mathrm{t}^{\top} \times 54$ & 4 & $\mathrm{P}^{\mathrm{P}}$ & 0.68 & $80-94$ \\
\hline 33 & ГMßRА 001 & VIC & PtTX56 & 4 & $\mathrm{P}$ & 0.91 & $104-136$ \\
\hline 34 & FМВRА 040 & 6 Fam & PtTX56 & 4 & $\mathrm{P}$ & 0.92 & $106-169$ \\
\hline 35 & EMBRA 116 & 6Fam & PtTX50 & 4 & $\mathrm{P}$ & 0.47 & $120-122$ \\
\hline 36 & FMBRA 066 & 6Fam & PtTX50 & 4 & $P$ & 0.95 & $131-172$ \\
\hline 37 & ГMßRА 225 & GFam & PtTX56 & 4 & $\mathrm{P}$ & 0.95 & $155-185$ \\
\hline 38 & FMBRA 094 & PFI & ] to $\times 54$ & 4 & $\mathrm{P}^{\mathrm{P}}$ & 0.80 & $220-221$ \\
\hline 39 & 1:MI3RA 048 & Pl:T & ]$^{3} \mathrm{t}[\times 58$ & 4 & $\mathrm{P}$ & 0.76 & $91-111$ \\
\hline 40 & EMBRA 043 & VIC & $\mathrm{P}^{3} \mathrm{tT} \times 56$ & 4 & $\mathrm{r}$ & 0.94 & $97-124$ \\
\hline 41 & ¿MBRA 011 & Ved & ]t $1 \times 56$ & 5 & $\mathrm{P}^{\mathrm{P}}$ & 0.97 & $126-159$ \\
\hline 42 & EMBRA 007 & 6Fam & $\operatorname{PtT} \times 56$ & 5 & $\mathrm{P}$ & 0.17 & $124-126$ \\
\hline
\end{tabular}


Table 1. - Continued.

\begin{tabular}{|c|c|c|c|c|c|c|c|}
\hline Index & Marker & Fluorophore & $\begin{array}{l}P C R \\
\text { prog }^{i}\end{array}$ & $\begin{array}{l}\text { Marker } \\
\text { rating }\end{array}$ & $\begin{array}{l}\text { Marker } \\
\text { poly }\end{array}$ & $U H_{e}^{4}$ & $\begin{array}{l}\text { Allele Range } \\
\text { (bp) }\end{array}$ \\
\hline 43 & Г:MBRA 083 & 6 Fam & PtTX56 & 5 & $\bar{P}$ & 0.32 & $68-72$ \\
\hline 44 & EMBRA 053 & $6 \mathrm{Fam}$ & PtTX56 & 5 & $\mathrm{P}$ & 0.94 & $121-134$ \\
\hline 45 & I:MI3RA 103 & Ned & P1'IX54 & 5 & P & 0.80 & $189-207$ \\
\hline 46 & ЕМBRA 039 & $\mathrm{VIC}$ & PLTX56 & 5 & $\mathrm{P}^{2}$ & 0.38 & $120-122$ \\
\hline 47 & EMBRA 028 & 6Fam & PLTX56 & 5 & $\mathrm{P}$ & 0.96 & $131-220$ \\
\hline 48 & T:MBRA 008 & $\mathrm{Ned}$ & P1TX56 & 5 & $\mathrm{P}$ & 0.88 & $143-169$ \\
\hline 49 & T:MBRA 187 & 6 Fam & PlTX58 & 5 & $\mathrm{P}$ & 0.85 & $183-189$ \\
\hline 50 & EMBRA 012 & 6Fam & PtTX60 & 5 & $P$ & 0.92 & $109-148$ \\
\hline 51 & FMBRA 941 & Ned & РtTХбо & 5 & $\mathrm{P}$ & 0.91 & $228-244$ \\
\hline 52 & I:MI3RA 088 & Ned & P1TX56 & 5 & $P$ & 0.89 & $107-1.35$ \\
\hline 53 & FMBRA 195 & Ned & Pt'l'X50 & 5 & $P^{2}$ & 0.65 & $192-203$ \\
\hline 54 & $\begin{array}{l}\text { I:MI3RA } \\
2000\end{array}$ & PHT & P1'IX600 & 5 & $\mathrm{P}^{3}$ & 0.53 & $237-239$ \\
\hline 55 & $\begin{array}{l}\text { ГМВЗRA } \\
2002\end{array}$ & PE:T & PtTX60 & 5 & $\mathrm{P}$ & 0.30 & $243-252$ \\
\hline 56 & FMBRA 206 & PET & PtTX58 & 5 & $\mathrm{P}$ & 0.77 & $273-302$ \\
\hline 57 & ГМГЗRА 098 & PET & PtTX54 & 6 & $\mathrm{P}$ & 0.96 & $201-230$ \\
\hline 58 & FMBRA 204 & PEFI & Pt'l'X56 & 6 & $P^{2}$ & 0.89 & $136-156$ \\
\hline 59 & ГMBRRA 042 & PET & PtTX56 & 6 & $\mathrm{P}$ & 0.94 & $107-141$ \\
\hline 60 & FMBRA 145 & $6 \mathrm{Fam}$ & PीTXón & 6 & $\mathrm{P}^{2}$ & 0.17 & $107-109$ \\
\hline 61 & I:MI3RA 175 & 6ram & $\mathrm{PlT} \times 56$ & 6 & $\mathrm{P}$ & 0.86 & $58-83$ \\
\hline 62 & EMBRA 210 & PET & PITX50 & 6 & $\mathrm{P}$ & 0.89 & $205-223$ \\
\hline 63 & EMBRA 182 & VIC & P1TX50 & 6 & $\mathrm{P}$ & 0.74 & $170-222$ \\
\hline 64 & EMBRA 214 & $\mathrm{Ned}$ & PITX54 & 6 & $P$ & 0.53 & $114-130$ \\
\hline 65 & EMBRA 169 & PET & PtTX54 & 6 & $\mathrm{P}$ & 0.84 & $117-143$ \\
\hline 66 & FMBRA 070 & $6 \mathrm{Fam}$ & Pt'l'X56 & 6 & $\mathrm{P}$ & 0.95 & $114-151$ \\
\hline 67 & ГМВВRA 209 & 6 Fam & PtTX58 & 6 & $\mathrm{P}$ & 0.53 & $115-132$ \\
\hline 68 & FMBRA 164 & Ned & Pt'TX60 & 6 & $\mathrm{P}$ & 0.95 & $113-144$ \\
\hline 69 & I:MIBRA 006 & VIC: & PrTx 58 & 6 & $\mathrm{P}$ & 0.53 & $121-135$ \\
\hline 70 & EMBRA 104 & PLT & PITX58 & 6 & $\mathrm{P}$ & 0.88 & $125-146$ \\
\hline 71 & LMBRA 242 & PET & PtTX56 & 6 & P & 0.69 & $143-150$ \\
\hline 72 & EPILMYB2 & 6Fam & PTX60 & 6 & $P^{2}$ & 0.91 & $150-175$ \\
\hline \multicolumn{6}{|c|}{ Me:in (SD) for 41 transferred and scorable loci (i.e. excl. EPILMYB2) } & $0.75(0.23)$ & \\
\hline
\end{tabular}

${ }^{1}$ PCR Program See AUCKLAND et al. (2002) for explanation of codes.

${ }^{2}$ Marker rating. A rating from 0 to 6 where 6 was optimal. See Methods.

${ }^{3}$ Marker Polymorphism in E. pilularis. - = no amplification; $\mathrm{M}=$ Monomorphic; $\mathrm{P}=$ Polymorphic.

${ }^{4}$ Unbiased Expected Heterozygosity = Nei's unbiased heterozygosity (NEI, 1978) for small sample sizes estimated in POPGENE v 1.31.

tions and taken from a larger range-wide collection of E. pilularis made for a study of population diversity (SHEPHERD et al., 2010).

At both Stages, loci were assessed for polymorphism and assigned a marker rating between 0 and 6 based on whether they transferred to the target taxon (E. pilularis), their degree of polymorphism, and amenability to automated scoring with GeneMapper V3.7 software (Applied Biosystems). Marker ratings were; $0=$ no amplification in source taxa, $1=$ amplification in source taxon only, $2=$ amplification in target taxon but monomorphic, $3=$ amplification in target taxon, polymorphic but can't score, $4=$ amplification in target taxon, polymorphic, manual score, $5=$ amplification in target taxon, polymorphic, assisted-automated score, $6=$ amplification in target taxon, polymorphic, automated score. Population diversity parameters were estimated using GenAlEx v6 (Peakall and Smouse, 2006).

At Stage 2, additional checks for Mendelian inheritance and the presence of null alleles were carried out using data from the F1 progeny. Genotypes were checked for congruence with their parental genotypes with each progeny expected to contain one allele from each parent. The only inconsistencies evident could be explained by the presence of a null allele in one of the parents. Here an offspring appeared as an apparent homozygote where it was expected to be heterozygous based on parental genotypes. 


\section{DNA extraction}

DNA was extracted from frozen or air dried foliage using the DNeasy 96 plant kit (Qiagen Pty Ltd, Doncaster, VIC). The frozen tissue protocol was used with the following modifications; $2 \%$ PVP-40 and $2.5 \mathrm{mg} / \mathrm{ml}$ charcoal were added to $600 \mu \mathrm{l}$ of Buffer API. The cell lysis step $65^{\circ} \mathrm{C}$ was increased to $30 \mathrm{~min}$ and an additional wash step with $100 \%$ ethanol was included. DNA was eluted in a final volume of $100 \mu \mathrm{l}$ of AE buffer (10 mM Tris-Cl, $0.5 \mathrm{mM}$ EDTA; $\mathrm{pH}$ 9.0). Starting material consisted of 8 leaf disks $(\sim 50 \mathrm{mg}$ of frozen or $10 \mathrm{mg}$ of dried tissue) punched from the leaf using a hole punch. DNA was quantified using Picogreen dye by comparing fluorescence of samples with standard amounts of dsDNA with fluorescence measured using an MWGt Sirius HT-TRF Fluorometer/spectrophotometer (MWG, Ebersberg, Germany). Total yields were $800 \pm 500 \mathrm{ng}($ mean $\pm \mathrm{SD})$.

\section{Microsatellite markers and PCR conditions}

A total of 71 microsatellite loci from the target taxa (E. grandis or E. urophylla) were tested for transfer to $E$. pilularis (Supplemental material 1). Additionally, the successful amplification of a microsatellite marker named EPILMYB2, (developed from a clone of the 2 gene from $E$. pilularis was also tested. The forward and reverse primers sequences were 5'-ATTTGCCCTCCTTCCCTTT-3' and 5'-CAGAATAATGAAAGAACAACACACA3 , respectively.

Microsatellite loci were amplified using a standardised PCR protocol described previously (SHEPHERD et al., 2006) with the PCR buffer modified to include bovine serum albumin (BSA) at the rate of $0.6 \mathrm{ug} / \mu \mathrm{l}$ and the amount of template reduced to $1 \mathrm{ng}$ per reaction in a total reaction volume of $12 \mu \mathrm{l}$. For Stages 1 and 2 of the transfer study (see below), each locus was amplified

Table 2. - Listing of 24 E. pilularis individuals used for the microsatellite transfer study. Sixteen individuals were selected from diverse locations (listed in increasing latitude) and eight individuals represent a pedigree of two parents and six controlled pollinated $\mathrm{F}_{1}$ offspring.

\begin{tabular}{|c|c|c|c|c|}
\hline$/ D$ & Genotype & $\begin{array}{l}\text { Provenance (Siate, collection location or nearby: } \\
\text { iownship }\end{array}$ & $\begin{array}{l}\text { Lat } \\
\text { (dec) }\end{array}$ & $\begin{array}{l}\text { Long } \\
\text { (dec) }\end{array}$ \\
\hline 10694 & $k 6737$ & QLD Nith. Fraser Island & -25.22 & 153.23 \\
\hline 10690 & $k 6733$ & QLD Sth. Fraser Island & -25.51 & 153.12 \\
\hline 10672 & $\mathrm{k} 6715$ & QLD Cooloola & -25.96 & 153.11 \\
\hline 4603 & clyb bso 340 & QLJ) Benarkin ( Taromeo & -26.89 & 152.14 \\
\hline 4613 & clyb bso 350 & QLD Googa & -26.97 & 152.01 \\
\hline 4618 & clyb bso 355 & QLD Deongwar & -27.28 & 152.24 \\
\hline 11019 & ddpil9 & NSW Double Duke & -29.17 & 153.21 \\
\hline 10982 & newpils & VSW Vewfoundland & -29.93 & 153.10 \\
\hline 10965 & conpils & NSW Conglomerate & -30.12 & 153.05 \\
\hline 10995 & bbpil5 & NSW Broken Bago & -31.51 & 152.70 \\
\hline 10932 & bby 002 & NSW Yerriyong SF & -35.02 & 150.58 \\
\hline 10713 & bbco03 & NSW Currawon & -35.60 & 150.18 \\
\hline 10731 & bbm010 & VSW Moruya & -35.79 & 150.07 \\
\hline 10740 & bbbogo & NSW Bodalla & -36.15 & 150.07 \\
\hline 10749 & en008 & NSW Vullica & -36.99 & 149.90 \\
\hline 10703 & ep003 & NSW Eden & -37.01 & 149.91 \\
\hline 10409 & 10135 & Conlrolled cross parent 1 & $11 \mathrm{a}$ & $11 a$ \\
\hline 10410 & 20047 & Controlled cross parent 2 & na & hat \\
\hline 10411 & polik15 & CC $10135 \times 20047$ - L.PIL & na & na \\
\hline 10412 & polik 17 & CC $10135 \times 20047-$ Г.PIL & na & $\mathrm{na}$ \\
\hline 10413 & $\mathrm{pol} / \mathrm{k} 1 \mathrm{~g}$ & CC 10135x20047- F.PII. & nă & $\mathrm{na}$ \\
\hline 10414 & polik 19 & CC. $10135 \times 20047-$ T.PIL & na & na \\
\hline 10415 & $\mathrm{pol} / \mathrm{k} 21$ & CC $10135 \times 20047-$ F.PII. & na & $\mathrm{na}$ \\
\hline 10416 & $\mathrm{pol} / \mathrm{k} 22$ & CC $10135 \times 20047$ - T.PIL & na & $11 \mathrm{a}$ \\
\hline
\end{tabular}


individually then pooled for analysis on an Applied Biosystems 3730 Genetic Analyser (Southern Cross Plant Genomics, Southern Cross University, Lismore, Australia). The forward primers of each primer-pair were labelled with one of the Applied Biosystems G5 dye set. Raw electropherogram data was processed using GeneMapper V3.7 software (Applied Biosystems) and exported to an Excel spreadsheet (Microsoft).

Table 3. - Amplification conditions and genetic diversity for 24 loci based on a set of 16 E. pilularis.

\begin{tabular}{|c|c|c|c|c|c|c|c|}
\hline Marker & $\begin{array}{l}\Gamma_{n}^{3} \\
(c)\end{array}$ & $\begin{array}{l}\text { Min allele } \\
\text { sise (bp) }\end{array}$ & $\begin{array}{l}\text { Max allele } \\
\text { sizc (bp) }\end{array}$ & $\begin{array}{l}\text { Regular } \\
\text { allclc } \\
\text { inlerval }\end{array}$ & Marker Rating." & $\mathrm{LHe}$ & $\begin{array}{l}\text { Multipl } \\
\mathrm{ex}\end{array}$ \\
\hline ЕМBRA 006 & 56 & 121 & 125 & $\mathrm{Y}$ & 6 & 0.33 & $B$ \\
\hline LMLRA 008 & 56 & 128 & 178 & $x$ & 5 & 0.92 & $B$ \\
\hline EMBRA 011 & 56 & 120 & 163 & $x$ & 6 & 0.92 & $C$ \\
\hline I:MBRA 012 & 58 & 108 & 148 & $x$ & 6 & 0.90 & A \\
\hline ГMBRA 028 & 56 & 56 & 86 & $x$ & 6 & 0.84 & $C$ \\
\hline ЕМBRA 039 & 56 & 114 & 123 & $\mathrm{Y}$ & 4 & 0.18 & \\
\hline l:MI3RA 042 & 56 & 117 & 162 & $x$ & 5 & 0.94 & C \\
\hline ЕMBRA 053 & 56 & 109 & 143 & $x$ & 5 & 0.88 & C \\
\hline TMBRA 070 & 56 & 114 & 181 & $x$ & 4 & 0.87 & \\
\hline LMBRA 098 & 54 & 199 & 254 & $x$ & 4 & 0.95 & \\
\hline ЕMBRA 103 & 54 & 192 & 207 & $x$ & 4 & 0.89 & \\
\hline F.MBRA 104 & 56 & 120 & 154 & $x$ & 6 & 0.78 & $B$ \\
\hline FMBRA 164 & 58 & 113 & 148 & $x$ & 6 & 0.93 & $\wedge$ \\
\hline LMBRA 169 & 54 & 113 & 158 & $x$ & 5 & 0.93 & $\mathrm{D}$ \\
\hline ¿MBRA 175 & 54 & 57 & 87 & $x$ & 6 & 0.83 & $\mathrm{D}$ \\
\hline LMBRA 182 & 50 & 156 & 223 & $\mathrm{Y}(\mathrm{M})$ & 3 & na & \\
\hline FMBRA 187 & 58 & 181 & 215 & $\mathrm{Y}$ & 6 & 0.82 & $\Lambda$ \\
\hline FMBR $А 204$ & 56 & na & na & na & 1 & na & \\
\hline FMBRA 209 & 56 & 115 & 132 & $\mathrm{Y}$ & 6 & 0.63 & $\mathrm{~B}$ \\
\hline EMBRA 210 & 54 & 186 & 233 & $x$ & 6 & 0.95 & $\mathrm{D}$ \\
\hline I:MBRA 214 & 54 & 114 & 130 & $\mathrm{Y}$ & 6 & 0.63 & 1) \\
\hline LMBRA 242 & 56 & 140 & 151 & $x$ & 4 & 0.78 & \\
\hline FMBRA 941 & 60 & 220 & 244 & $\mathrm{Y}$ & 4 & 0.88 & \\
\hline Г:PILMYT32： & 58 & 150 & 177 & $x$ & 6 & 0.73 & $\Lambda$ \\
\hline Mean & & & & & & 0.80 & \\
\hline $\mathrm{ST}$ & & & & & & 0.04 & \\
\hline
\end{tabular}

${ }^{1}$ Locus identified in $E$. pilularis. See methods.

${ }^{2} \mathrm{~T}_{\mathrm{a}}$ - Touchdown program starting annealing temperature.

${ }^{3}$ Regular allele intervals were recorded as "yes" if allele sizes fitted the expected size according to the size of the repeat motif i.e. 2 bp pair intervals for a di-nucleotide repeat motif. An (M) indicates possible multilocus primer-pair.

${ }^{4} \mathrm{UH}_{\mathrm{e}}$ is Nei's unbiased expected heterozygosity for a small sample (NEI, 1978),

${ }^{5}$ Marker rating. Each marker was assigned a rating of 0-6 with 6 the most optimal based on transfer and scoring attributes. See Methods. 
An independent estimate of the divergence amongst eucalypt groups using a fragment of the CCR gene.

A total of 55 CCR sequences from Eucalyptus $(\mathrm{n}=35)$, Corymbia $(\mathrm{n}=18)$ and Angophora $(\mathrm{n}=2)$ were aligned manually using the alignment explorer of Mega v4 (TAMURA et al., 2007). Fifty sequences were obtained from GenBank and a further five $E$. pilularis sequences were obtained by cloning and sequencing as described in Sexton et al. (2010) (A list of the Genbank accession numbers and source organism is given in available from author upon request.

Once an approximate alignment was obtained, a conserved $636 \mathrm{bp}$ fragment of the CCR gene was used to estimate the mean between group divergences amongst sections, subgenera or genera of eucalypts. The fragment represents conserved regions including Exon 4 and part of Intron 5 and Exon 5. Sequences were grouped at the genus, subgenus or section level according to the taxonomy of BROOKER (2000) as shown in Supplemental Material 2. The mean between-groups p-distance was estimated using the "compute between group means" and the "pairwise deletion" options in the Distance module of Mega v4.

\section{Results}

\section{Transfer assessment - Stage 1}

From the set of 71 loci tested for transfer, nine were not considered as candidates for transfer because they failed to amplify on the $E$. grandis control samples under the PCR conditions used in this study (Table 1; Rating zero). Ninety-seven percent (60) of the remaining 62 loci (Table 1; Rating 1 or higher) amplified in at least one of the six $E$. pilularis. The EPILMYB2 microsatellite marker also successfully amplified in both $E$. grandis and E. pilularis samples.

Of the 60 transferred loci, 16 could not be reliably scored due to a complex of peaks as a result of either multi-locus or non-specific amplification and were eliminated from further analysis (Table 1; Rating 3). A further three loci were monomorphic in E. pilularis (Table 1; Rating 2). Thirty-one loci were given the highest rating (5 or 6 ) for automated scoring suitability (Table 2), indicating that they were polymorphic, single-locus, and possessed electropherogram peak characteristics amenable to automated scoring. The remaining 10 loci were polymorphic but rated 4 indicating their characteristics were less ideal for automated analysis. The mean unbiased expected heterozygosity for these 41 markers (Rankings 4-6) was (mean (SD)) 0.75 (0.23). The EPILMYB2 marker developed for this study from $E$. pilularis sequence was also polymorphic and possessed characteristics suitable for automated scoring, with an unbiased expected heterozygosity of 0.91 .

\section{Transfer assessment - Stage 2}

Twenty four loci, including the EPILMYB2 marker, were selected from the pool of markers with a rating of 5 or 6 on the basis of the compatibility of their $\mathrm{T}_{\mathrm{a}}$ and PCR product size for grouping into sets of loci suitable for multi-plex PCR. These markers were re-assessed for amenability to automated scoring and polymorphism. Two loci, EMBRA 204 and EMBRA 182 were eliminated from further analysis as they could not to be scored and assessed for diversity due to weak signal levels under the pooled analysis of PCR products used here (Table 3 ). The genetic diversity of remaining transferred loci was not different $\left(\mathrm{n}=21 ;\right.$ av. $\mathrm{UH}_{\mathrm{e}}=0.81 \pm 0.19$; one-sided $\mathrm{t}$ test unequal variances $\mathrm{p}$-value $=0.22$; nb EPILMYB2, EMBRA 204 and 182 excluded; Table 3) from the entire set of transferred and polymorphic loci ( $n=41$; see above).

Analysis of parental and offspring genotypes for the controlled pollinated pedigree revealed that no nonparental alleles were observed in the $F_{1}$. However, null alleles probably did occur in EMBRA 070 (data not shown). Most loci (18 out the 24) did not exhibit the

Table 4. - Pairwise distances between Angophora, Corymbia and Eucalyptus based on sequence diversity within the CCR gene (636bp).

\begin{tabular}{|c|c|c|c|c|c|c|c|c|c|c|}
\hline & \multirow{2}{*}{$\begin{array}{l}\text { Angophora } \\
A\end{array}$} & \multicolumn{5}{|c|}{ Corymbia } & \multicolumn{4}{|c|}{ Eucalyptus } \\
\hline & & $C B$ & $C R$ & $\mathrm{CP}$ & $C C$ & $C O$ & $E P$ & $E A$ & $S E$ & $S M$ \\
\hline A & & & & & & & & & & \\
\hline $\mathrm{CB}$ & 0.05 & & & & & & & & & \\
\hline $\mathrm{CR}$ & 0.04 & 0.03 & & & & & & & & \\
\hline $\mathrm{CP}$ & 0.05 & 0.03 & 0.02 & & & & & & & \\
\hline$C C$ & 0.04 & 0.01 & 0.01 & 0.01 & & & & & & \\
\hline $\mathrm{CO}$ & 0.04 & 0.04 & 0.02 & 0.02 & 0.01 & & & & & \\
\hline $\mathrm{E}^{\mathrm{P}}$ & 0.15 & 0.12 & 0.14 & 0.14 & 0.14 & 0.14 & & & & \\
\hline$E A$ & 0.13 & 0.12 & 0.12 & 0.12 & 0.12 & 0.14 & 0.00 & & & \\
\hline $\mathrm{SE}$ & 0.12 & 0.12 & 0.12 & 0.11 & 0.11 & 0.13 & 0.05 & 0.05 & & \\
\hline $\mathrm{SM}$ & 0.13 & 0.12 & 0.12 & 0.11 & 0.11 & 0.13 & 0.05 & 0.04 & 0.02 & \\
\hline SI. & 0.13 & 0.12 & 0.12 & 0.11 & 0.11 & 0.13 & 0.05 & 0.04 & 0.02 & 0.01 \\
\hline
\end{tabular}

Taxa codes: A = Genus Angophora; CP, CB, CR,CC, CO are sections Politaria, Blakearia, Rufaria, Cadagaria and Ocharia of the genus Corymbia; $S E, S M$ and $S L$ are the sections, Exertaria, Maidenaria and Latoangulatae of the genus Eucalyptus, subgenus Symphyomyrtus; EP and EA are sections Pseudophloius and Aromatica of genus Eucalyptus subgenus Eucalyptus. 
Table 5. - Rates of transfer of microsatellite markers at different taxonomic levels within eucalypts.

\begin{tabular}{|c|c|c|c|c|c|c|}
\hline Focal taxa & $\begin{array}{l}\text { Non-focal } \\
\text { laxa }\end{array}$ & $\begin{array}{l}\text { No. } \\
\text { of } \\
\text { loci }\end{array}$ & $\begin{array}{l}\text { Within } \\
\text { sub- } \\
\text { genera } \\
(\%)\end{array}$ & $\begin{array}{l}\text { Across } \\
\text { subgenera } \\
(\%)\end{array}$ & $\begin{array}{l}\text { Across } \\
\text { genera } \\
\%)\end{array}$ & Reference \\
\hline E. nitens & $\begin{array}{l}\text { C. } \\
\text { maculata } \\
2 \text { Mono. } \\
4 \text { Symph. }\end{array}$ & 4 & 100 & 50 & nil & $\begin{array}{l}\text { (BYRNE et al., } \\
1996)\end{array}$ \\
\hline E. grandis & $\begin{array}{l}\text { E. dunnii, } \\
\text { E. cloeziana } \\
\text { E. pilularis } \\
\text { C. } \\
\text { citriodora }\end{array}$ & 100 & $80-100$ & $55-59$ & 20 & $\begin{array}{l}\text { (KIRST et al, } \\
1997 \text { ) }\end{array}$ \\
\hline $\begin{array}{l}\text { Corymbia } \\
\text { citriodora } \\
\text { spp } \\
\text { variegata }\end{array}$ & $\begin{array}{l}\text { C. henryi, } \\
\text { C. } \\
\text { watsoniana, } \\
\text { C. } \\
\text { intermedia } \\
\text { E. grandis } \\
\text { E. globulas } \\
\text { E. nitens } \\
\text { E. pilularis } \\
\text { E. } \\
\text { acmenoides } \\
\text { E. cloeziana }\end{array}$ & 14 & 100 & $57-79$ & $21-53$ & $\begin{array}{l}\text { (JoNES et al., } \\
2001)^{1}\end{array}$ \\
\hline E. grandis & $\begin{array}{l}\text { Corymbia } \\
\text { ssp. }\end{array}$ & 73 & & & 90 & $\begin{array}{l}\text { (SIJLPIIERD et } \\
\text { al., 2006) }\end{array}$ \\
\hline E. sieberi & E. nitens & 8 & & 75 & & $\begin{array}{l}\text { (GI_AUIIT7 el } \\
\text { al., 2001) }\end{array}$ \\
\hline E. globulus & $\begin{array}{l}6 \text { Sympho. } \\
4 \text { Mono. } \\
2 \text { Corymbia } \\
\text { spp. } \\
2 \\
\text { Angophora }\end{array}$ & 13 & 88 & 69 & $53-69$ & $\begin{array}{l}\text { (STLANE et al., } \\
2001)^{2}\end{array}$ \\
\hline E. grandis & E.pilularis & 71 & & 96 & & This study \\
\hline
\end{tabular}

${ }^{1}$ Transfer rates may be inflated by non-specific PCR products.

2 Transfer rates exclude non-specific PCR products.

allele sizes consistent with the size of their nucleotide repeat motif. For example, loci having di-nucleotide repeats were found to have both odd and even-sized alleles (Table 3).

An independent estimate of the divergence amongst eucalypt groups at a fragment of the CCR gene.

Sequence variation in an alignment of CCR gene was used to generate estimates of divergence between members of the Symphyomyrtus and Eucalyptus subgenera as a comparison to divergence inferred by the transfer rate for microsatellite markers (Table 4). A total of $636 \mathrm{bp}$ from the CCR gene, consisting of $172 \mathrm{bp}$ of intronic and 464 bp exonic sequence from Exons 4 and 5 and Intron 4 (alignment not shown) was aligned for 55 eucalypts (See Supplemental Material 1 for list of species and Genbank accession numbers). The percentage divergence between the source section for microsatellite marker origin (i.e. Section Latoangulatae in the Subgenus Symphyomyrtus; estimate based on 12 individuals from 8 species) and target section (Section Pseudophloius from the Subgenus Eucalyptus; estimate based on $5 E$. pilularis) averaged $4 \%$ and was congruent with the level of divergence between another subgenus Eucalyptus representative, $E$. amygdalina $(\mathrm{n}=1)$ and Section Latoangulatae representatives (Table 4). The level of divergence evident between subgenera therefore, was around two fold that of the largest divergence amongst members from different sections of the subgenus Symphyomyrtus (i.e. between SE and SM, or SE and SL; ie. both were $2 \%$; Table 4). We also note that the divergence between Eucalyptus sections and Corymbia sections or representatives of the Angophora genus, ranged between 0.11 and $0.14 \%$, which was about 2-3 fold the magnitude of divergence evident among subgenera of Eucalyptus (0.04-0.05). Also noteworthy was the consistently lower inter-generic divergences evident between representatives of Angopho- 
ra and Corymbia genera (i.e. 0.04 to 0.05), compared with the Eucalyptus to Angophora or Corymbia contasts, consistent with the more recent view of sister taxa relationship of Angophora and Corymbia (Table 4).

\section{Discussion}

Assessing and reporting microsatellite transfer rates provides information on the evolution of microsatellite loci and should lead to methods that improve transfer rates (PRIMMER et al., 2005). We found that transfer of microsatellite loci across subgenera of Eucalyptus can be highly efficient, with 60 out 62 loci that transferred to the laboratory (i.e. amplified on the source taxon ie. $E$. grandis), transferred across subgenera, and all but 3 exhibited polymorphism in the target taxon.

The transfer rate for the present study tended to be high compared to previously published studies of subgeneric or wider transfer of microsatellite marker in eucalypts which have generally been moderate (i.e. 50-75\%) (Table 5). A key exception was a study of intergeneric transfer between Eucalyptus and Corymbia where a transfer rate of $90 \%$ was recorded (SHEPHERD et al., 2006). These two studies were unique among the tabulated examples in that transfer was assessed in a laboratory other than the one where the markers were developed. Consequently, prior to estimation of transfer efficiencies, loci had to be transferred to the laboratory and amplify on control samples of the source taxon under conditions where there were both deliberate and unintended (i.e. differences between PCR machines, enzymes or other reagents) modifications to the PCR parameters.

In the present study, nine loci were eliminated for consideration in the transfer study because they did not amplify on the source taxon under the imposed PCR conditions. Hence the process of transferring loci among laboratories may have the unintended consequences of filtering for loci with wider PCR optima. In doing so, this process of filtering is further likely to identify loci that are more robust to less-than-perfect primer-template matching, thus leading to inadvertent selection of loci more likely to transfer across species. This process of ascertainment bias, may have helped identify loci that will transfer more frequently across species, and have contributed to the high rates of transfer recorded for the two studies in question.

The adoption of the technique of touchdown PCR may have been a second factor augmenting high realised transfer rates in the present study relative to some earlier studies. Touchdown PCR is a technique invented to circumvent the need to empirically optimise a fixed annealing temperature $\left(\mathrm{T}_{\mathrm{a}}\right)$ for PCR, because of the difficulties of estimating melting temperatures for templates, or because the template sequence is unknown, hence it a technique particularly valuable for crossspecies transfer of loci (Roux, 1994). Optimal $\mathrm{T}_{\mathrm{a}}$ may not have been tested in the two earlier transfer studies that used fixed $\mathrm{T}_{\mathrm{a}}$ (JONEs et al., 2001; STEANE et al., 2001) as neither report empirical testing for a $\mathrm{T}_{\mathrm{a}}$ optimum. Higher rates for studies adopting touchdown PCR for crossspecies amplification, where the aim is to commence cycling at a $\mathrm{T}_{\mathrm{a}}$ above the $\mathrm{T}_{\mathrm{a}}$ optimum and undergo stepwise decreases as cycling progresses, is consistent with studies of increased success rates for microsatellite markers transfer in birds when fixed annealing temperatures are lowered (PRIMMER et al., 1995).

In addition to the technical factors discussed, high transfer rates would not be possible were the background biological factors also not suitable. The success of cross-species transfer of microsatellite markers is related to evolutionary distance of the transfer which affects both the divergence in primer site sequence, and insertions in the intervening sequence, and therefore the success of PCR (HEDGECOCK et al., 2004; PRIMMER et al., 2005).

Early predictions of high rates of microsatellite marker transfer among eucalypts based on experience with relatively small numbers of microsatellite markers and sequence conservation evident at other genetic loci have largely been borne out (BYRNE et al., 1996; GLAUBITZ et al., 2003; KIRST et al., 1997). And, as the present study shows, despite the difficulties with using SSR transfer rates as a measure of evolutionary divergence (due to ascertainment bias for example), high transfer rates are nonetheless congruent with the accumulating evidence of high sequence conservation in Eucalyptus.

There remains relatively few published phylogenetic studies spanning subgenera of Eucalyptus or the eucalypts more broadly (Eucalyptus, Corymbia and Angophora) (Recently reviewed in GRATTAPAGLIA et al. (2012)). The study based on internal transcribed spacer (ITS) sequence remains among the most comprehensive, and indicate sequence divergence between subgenera in eucalypts tends to the lower end of that found in sections or genera of other angiosperms (STEANE et al., 1999; See Table 2 of BALDWIN et al. (1995)). Estimates of percentage pairwise divergence between two members of Eucalyptus subgenera ranged from 1.2 to $3 \%$ and were not much different to those within each subgenus $(1.9 \%$ Symphyomyrtus; $1.0 \%$ Monocalyptus).

Our assessment of subgenus divergence using the CCR gene revealed remarkably similar and low sequence divergence among Eucalyptus subgenera. The percentage divergence in CCR between the source group (Section Latoangulatae $\mathrm{n}=12$ individuals from 8 species) and target (Section Pseudophloius $\mathrm{n}=5 \mathrm{E}$. pilularis), averaged $4 \%$, equal to that between another subgenus Eucalyptus representative, E. amygdalina $(\mathrm{n}=1)$ and Section Latoangulatae representatives.

Our analysis of the CCR fragment also provided estimates of inter-generic divergence that revealed divergence between Eucalyptus and Angophora or Corymbia was 2 to 3 fold that among the Eucalyptus subgenera. This again augers well for inter-generic SSR transfer, as was previously reported, but clearly the relationship between sequence divergence and transfer rates is not linear and many other factors influence this relationship. As an aside, we note also the closer affinity between the Corymbia and Angophora genera consistent with more recent views of their taxonomic status (HILL and Johnson, 1995; LAdiges and Udovicic, 2000), and 
favourable prospects for transfer of SSR loci developed in Corymbia to its sister genus (SHEPHERD et al., 2006).

The present study reports a set of 22 well-characterised microsatellite markers for use in $E$. pilularis. These loci are likely to be robust to fluctuations in PCR conditions and amenable to use in other species as well, a function of the inadvertent ascertainment bias that occurs when loci are transferred among laboratories that may favour loci with broad PCR optima. Although issues of ascertainment bias muddle estimates of evolutionary divergence, high microsatellite transfer rates for eucalypts are in keeping with the accumulating evidence of high sequence level conservation in the group.

\section{Funding}

This study was funded by the Cooperative Research Centre for Forestry and Forests NSW.

\section{Acknowledgements}

The author thanks Forests NSW staff and contractors, in particular, S. Boyton, R. Allen, R. Shiels, H. SMith, G. Heagney, C. Moran, W. Varley, D. Klienig and J. Ross for help in foliage collections and acknowledge the assistance of the DNA Bank, Southern Cross Plant Genomics, and K. NoRTHCOTT for the assistance with laboratory work, T. SEXTON and L. McManus for development of the EPILMYB2 locus, and C. Harwood for comments on the manuscript.

\section{References}

Auckland, L. D., T. Bui, Y. Zhou, M. Shepherd and C. G. WiLliams (2002): Conifer Microsatellite Handbook. Corporate Press, Raleigh NC.

Baldwin, B. G., M. J. Sanderson, J. M. Porter, M. F. Wojciechowski and C. S. CAMPBELl et al. (1995): The ITS region of nuclear ribosomal DNA: A valuable source of evidence on angiosperm phylogeny. Ann Missouri Botanical Gardens 82: 247-277.

Barbara, T., C. Palma-Silva, G. M. Paggi, F. Bered and M. F. FAY et al. (2007): Cross-species transfer of nuclear microsatellite markers: potential and limitations. Molecular Ecology 16: 3759-3767.

Brondani, R. P. V., C. Brondani and D. Grattapaglia (2002): Towards a genus-wide reference linkage map for Eucalyptus based exclusively on highly informative microsatellite markers. Molecular Genetics \& Genomics 267: 338-347.

Brondani, R. P. V., C. BRondani, R. TARChini and D. GratTAPAGLIA (1998): Development, characterisation and mapping of microsatellite markers in Eucalyptus grandis and E. urophylla. Theoretical and Applied Genetics 97: 816-827.

Brondani, R. P. V., E. R. Williams, C. Brondani and D. GRATTAPAGLIA (2006): A microsatellite-based consensus linkage map for species of Eucalyptus and a novel set of 230 microsatellite markers for the genus. BMC Plant Biology 6: 1-16.

Brooker, M. I. H. (2000): A new classification of the genus Eucalyptus L'Her. (Myrtaceae). Australian Systematic Botany 13: 79-148.
Byrne, M., M. I. Marquez-Garcia, T. URen, D. S. SMith and G. F. MoRAN (1996): Conservation and genetic diversity of microsatellite loci in the genus Eucalyptus. Australian Journal of Botany 44: 331-341.

EldRidGe, K., J. Davidson, C. HARWOOD and G. van WyK (1994): Eucalypt domestication and breeding. Oxford University Press, Oxford.

Glaubitz, J., EmebIRI and G. Moran (2001): Dinucleotide microsatellites in Eucalyptus sieberi: Inheritance, diversity and improved scoring of single base differences. Genome 44: 1041-1045.

Glaubitz, J. C., H. X. Wu and G. F. Moran (2003): Impacts of silviculture on genetic diversity in the native forest species Eucalyptus sieberi. Conservation Genetics 4: $275-287$.

GRATTAPAGLIA, D. and M. KIRST (2008): Eucalyptus applied genomics: from gene sequences to breeding tools. New Phytologist 179: 911-929.

Grattapaglia, D., R. E. Vaillancourt, M. Shepherd, B. Thumma and W. J. Foley et al. (2012): Progress in Myrtaceae genomics; Eucalyptus as the pivotal genus. Tree Genetics and Genomes 8: 463-508.

Hedgecock, D., G. Li, S. Hubert, K. Bucklin and V. Ribes (2004): Widespread null alleles and poor cross-species amplification of microsatellite DNA loci cloned from the Pacific oyster, Crassostrea gigas. Journal of Shellfish Research 23: 379-385.

Henson, M. and H. J. Smith (2007): Achievements in forest tree genetic improvement in Australia and New Zealand. 1. Eucalyptus pilularis Smith tree improvement in Australia. Australian Forestry 70: 4-10.

HiLL, K. D. and L. A. S. Johnson (1995): Systematic studies in the eucalypts 7. A revision of the bloodwoods, genus Corymbia (Myrtaceae). Telopea 6: 185-504.

Jones, M., R. Stokoe, M. Cross, L. Scott and T. Maguire et al. (2001): Isolation of microsatellite loci from spotted gum (Corymbia variegata), and cross-species amplification in Corymbia and Eucalyptus. Molecular Ecology Notes 1: 276-278.

Kirst, M., R. P. V. Brondani, C. Brondani and D. GrattaPAGLIA (1997): Screening of designed primer pairs for recovery of microsatellite markers and their transferability among species of Eucalyptus, pp. 167-170. In: Proceedings of the IUFRO Conference on Silviculture and Improvement of Eucalypts, Salvador, Brazil.

LADIGES, P. Y. and F. Udovicic (2000): Comment on a new classification of the eucalypts. Australian Systematic Botany 13: 149-152.

NEI, M. (1978): Estimation of average heterozygosity and genetic distance from a small number of individuals. Genetics 89: 583-590.

Peakall, R., S. Gilmore, W. Keys, M. Morgante and A. RAFAlsKi (1998): Cross-species amplification of soybean (Glycine max) simple sequence repeats (SSRs) within the genus and other legume genera: implications for the transferability of SSRs in plants. Molecular Biology and Evolution 15: 1275-1287.

PEAKAlL, R. and P. E. SMOUSE (2006): GENALEX 6: genetic analysis in Excel. Population genetic software for teaching and research. Molecular Ecology Notes 6: 288-295.

Poke, F. S., R. E. Vaillancourt, B. M. Potts and J. B. RIED (2005): Genomic research in Eucalyptus. Genetica 125: 79-101. 
Primmer, C. R., A. P. Moller and H. Ellegren (1995): Resolving Genetic Relationships With Microsatellite Markers - a Parentage Testing System For the Swallow Hirundo Rustica. Molecular Ecology 4: 493-498.

Primmer, C. R., J. N. Painter, M. T. Koshinen, J. U. Palo and J. MERILA (2005): Factors affecting avain crossspecies microsatellite amplification. Journal of Avian Biology 36: 348-360.

Roux, K. H. (1994): Using mismatched primer-template pairs in touchdown PCR. BioTechniques 16: 812-814.

SCHLOTTERER, C. (2001): Genealogical inference of closely related species based on microsatellites. Genetic Research, Cambridge 78: 209-212.

Sexton, T., R. J. Henry, L. J. McManus, S. Bowen and M. SHEPHERD (2010): Capture of assay template by multiplex PCR of long amplicons for genotyping SNPs and InDels with MALDI-TOF mass spectrometry. Molecular Breeding 25: 471-480.

Shepherd, M., S. KASEM, D. LeE and R. HenRy (2006): Construction of microsatellite linkage maps for Corymbia. Silvae Genetica 55: 228-238.
ShePherd, M. and C. A. RAYMOND (2010): Species delineation and gene flow in the Blackbutts (Genus Eucalyptus Subgenus Eucalyptus Section Pseudophloius). Conservation Genetics 11: 1965-1978.

Shepherd, M., T. R. Sexton, D. Thomas, M. Henson and R. J. HENRY (2010): Geographical and historical determinants of microsatellite variation in Eucalyptus pilularis. Canadian Journal of Forest Research 40: 1051-1063.

Steane, D. A., G. E. McKinnon, R. E. Vaillancourt and B. M. PotTs (1999): ITS sequence data resolve higher level relationships among the eucalypts. Molecular Phylogenetics and Evolution 12: 215-223.

Steane, D. A., R. E. Vaillancourt, J. Russell, W. Powell, D. Marshall et al. (2001): Development and characterisation of microsatellite loci in Eucalyptus globulus (Myrtaceae). Silvae Genetica 50: 89-91.

TAmura, K., J. Dudley, M. Nei and S. Kumar (2007): MEGA4: Molecular Evolutionary Genetics Analysis (MEGA) software version 4.0. Molecular Biology and Evolution 24: 1596-1599. 